\title{
A Review of Sub-Scale Test Methods to Evaluate the Friction and Wear of Ring and Liner Materials for Spark- and Compression Ignition Engines
}

November 2001 
Metals and Ceramics Division

\section{A Review of Sub-Scale Test Methods to Evaluate the Friction and Wear of Ring and Liner Materials for Spark- and Compression Ignition Engines}

Peter J. Blau

November 2001

Prepared for

U.S. Department of Energy, Assistant Secretary for Energy Efficiency and Renewable Energy,

Office of Transportation Technologies

Prepared by

OAK RIDGE NATIONAL LABORATORY

Oak Ridge, Tennessee 37831-6285

managed by

UT-BATTELLE, LLC

for the

U.S. DEPARTMENT OF ENERGY

Under contract DE-AC05-00OR22725 


\section{CONTENTS}

Executive Summary ……………................................................................ vii

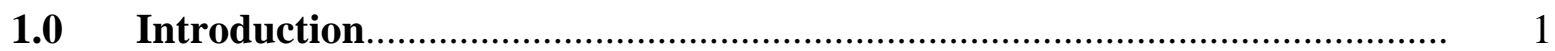

1.1 Factors Involved in Simulations ..............................................................

1.2 Levels of Testing Scale............................................................................. 4

2.0 Annotated Literature Review of Ring/Cylinder Bore Studies....................... 5

3.0 Conclusions and Recommendations .......................................................... 12

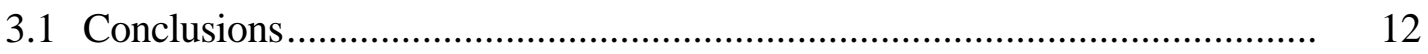

3.2 Recommendations.............................................................................. 13

Appendix A - Factors Affecting Ring/Liner Tribology ........................................... 16 


\section{Preface}

Energy resources are of strategic interest to the United States, and the transportation sector is a major consumer of energy. In 1998 the transportation sector accounted for about $27.7 \%$ of the total U.S. energy consumption. ${ }^{*}$ The United States Department of Energy, Office of Energy Efficiency and Renewable Energy, Office of Transportation Technologies, is sponsoring programs to develop new scientific and technological strategies that will improve the efficiency of vehicles and therefore reduce the consumption of vital U.S. energy resources.

Friction, lubrication, and wear (tribology) issues impact the energy efficiency of vehicles in many ways, and therefore it is important to develop new design concepts, lubrication strategies, and tribomaterials (materials whose functions involve friction or wear) for engine and drive-train components. The current work supports that aim.

Testing is a significant component of materials development. Full-scale vehicle tests or instrumented engine test cell programs can be very expensive, and industry seeks to reduce the cost of obtaining engineering design and selection data for materials, lubricants, and coatings. Any useful subscale test (simulative test) must rank materials in the same order of merit as they would behave in the end-use applications, which in the present case are piston rings and cylinder bores. This study was conducted to review past laboratory-scale test methods and to assess their validity for ranking materials and lubricants for use in engines. It concludes with a summary and recommendations for future research.

Peter J. Blau, Ph.D.

Senior Research Engineer

Metals and Ceramics Division

Oak Ridge National Laboratory

* Transportation Energy Data Book, Edition 19, Oak Ridge National Laboratory report 6958 (1999), p. 2-4. 


\section{Executive Summary}

A review was conducted of past laboratory-scale test methods and to assess their validity for ranking materials and lubricants for use as piston and liner materials in compression-ignition (CI) and spark-ignition (SI) engines. Most of the previous work was aimed at simulating SI engine environments. This report begins with a discussion of the numerous factors that can affect the validity of an approach to simulating engine conditions in a laboratory. These include not only mechanical, chemical and thermal factors, but also human factors as regards how the vehicle is operated and maintained. The next section provides an annotated review of open literature publications that address the issues of laboratory simulation of engine components. A comparison of these studies indicates a lack of sufficient standardization in procedures to enable a systematic comparison of one publication to another. There were just a few studies that compared several laboratory test methods to engine test results, and these indicated that some test methods correlate, at least qualitatively, better than others. The last section provides a series of recommendations for improving the accuracy and validity of laboratory-scale simulations of engine behavior. It became clear that much of the engine wear damage occurs during start-up when the engine is cold, and this calls into the question the usefulness of test methods that attempt to simulate steady-state running conditions. It is recommended that a new standard test method, perhaps developed with the help of the ASTM wear and erosion committee, be

developed. It would use cold start-up conditions in the presence of degraded oil, or simulated degraded oil. 


\subsection{Introduction}

The performance of mechanical components is limited by the capabilities of the materials from which they are made. Machine designers must make compromises in performance for a number of reasons. Sometimes, engineering materials of low enough cost are not available to meet the demanding requirements of new equipment designs and less than optimal materials must be used. Sometimes using a premium grade material or surface treatment is the only way to meet the design requirements. The latter tends to be the case for high-performance military applications or high-end automobiles and trucks. Compromises between performance and cost are particularly common in the highly-competitive ground transportation industry.

Diesel engines, which by most measures are more fuel-efficient than spark ignition engines, comprise the major propulsion systems for on-highway heavy vehicles, like Class 8 trucks. Diesel engine technology has been driven in recent years by increasing pressure from two sources: (1) the desire to improve fuel economy, and (2) the need to meet increasingly stringent emissions requirements. Designers have used a broad spectrum of strategies to improve performance and lower emissions. Widening the choice of structural materials offers designers more opportunity to optimize engines and meet these two important goals. Some of the needs for new materials involves the use of tribomaterials - i.e., materials whose functions in some way involve friction, lubrication, and surface damage resistance. Both the materials used for friction- or wear-critical parts and liquid lubricants are broadly considered to be tribomaterials.

When new materials, lubricants, or surface treatments are developed, it is important to be able to evaluate their potential to improve engine performance in a fast, efficient, and cost-effective way. That requirement poses a significant challenge for the test engineer because small changes in the way materials are exposed to the mechanical, chemical, and thermal aspects of their surroundings can affect their friction and wear behavior. Therefore, the ultimate challenge becomes one of identifying and controlling the key factors needed to enable materials, lubricants, and coatings to be tested in the laboratory in such a way that directly correlates with their performance in the end application. The degree of confidence by engineering decision-makers in laboratory test data must be based on laboratory-field correlations.

\subsection{Factors Involved in Simulations}

In the present context, the term simulation refers to a physical test that attempts to duplicate the key factors in an engine, not a mathematical simulation that generates results based on a set of starting assumptions and boundary conditions. Figure 1 schematically depicts six main categories of effects that must be addressed in developing useful laboratory-scale tests for candidate engine materials and lubricants. Many of the factors listed in each box are interrelated. For example, the sliding speed and contact pressure can combine to produce frictional heating. Frictional heating, in turn, can alter the tribochemistry of the exposed surfaces. Thus, a change in one factor can affect several other factors. This degree of complexity makes it difficult or impossible to conduct friction or wear experiments in which only one parameter is treated as the independent variable and everything else is 'held constant.' 


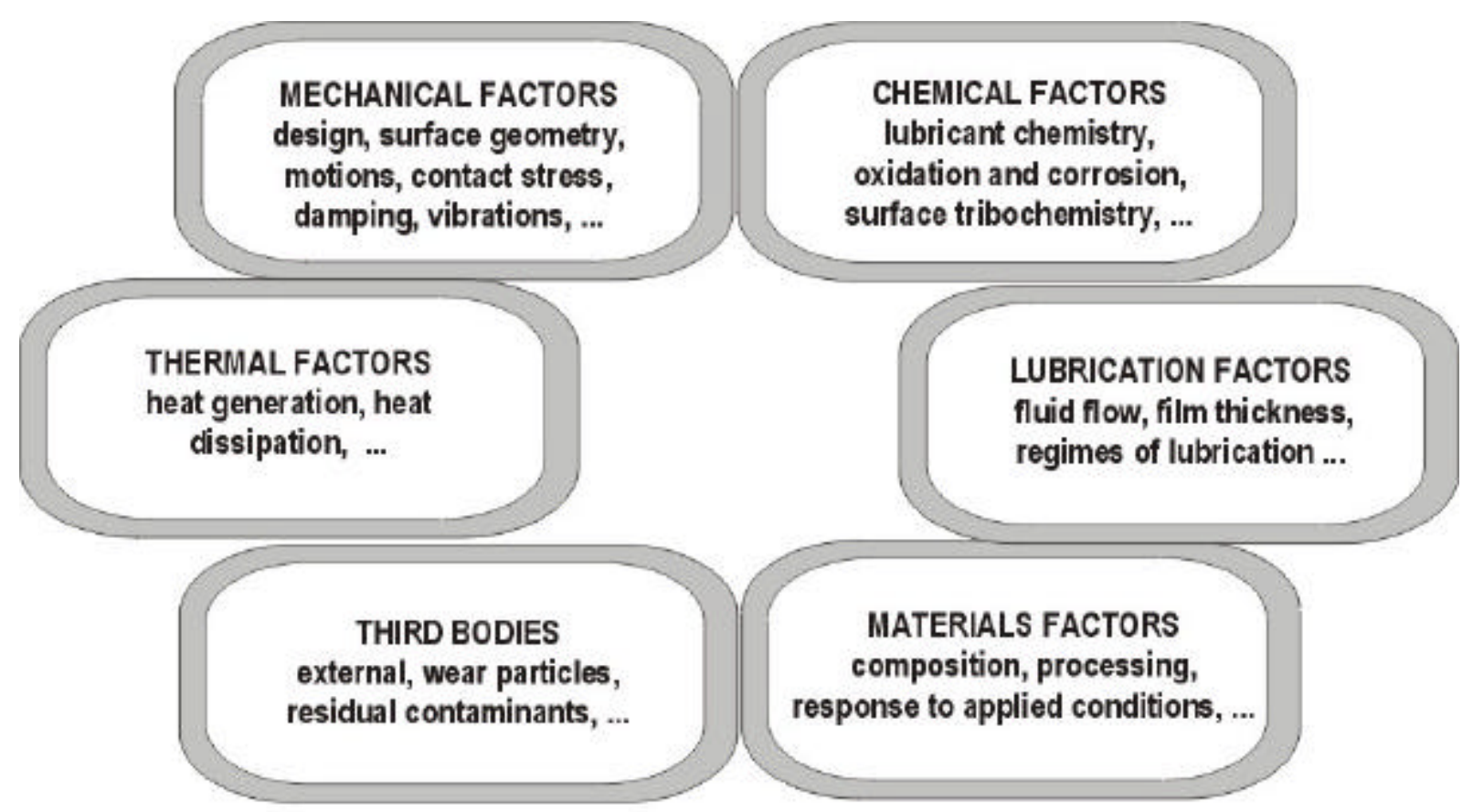

Figure 1. General categories of factors that must be considered in the course of developing accurate simulations of friction and wear-critical parts in diesel engines.

1.1.1 Mechanical factors include much more than just the stresses applied to surfaces and the speed of relative motion. They include the periodicity or intermittency of relative motion, the stiffness and damping capacity of the system, and the manner in which surfaces meet at macro and microscales. Despite heroic attempts to control the quality of the engines we build, we still live in an imperfect world. Machines are designed and built by imperfect people from imperfect materials in imperfect factories, and the result of this is phenomena like residual assembly stresses, surface finish defects, contamination by hard particles, and alignment errors in the assembled components. Some of these effects are subtle and difficult to detect during manufacturing, but they can nevertheless have an effect on the life and performance of an engine. Simulating such subtle effects is not easy and can widen the gap between laboratory testing and field response.

1.1.2 Chemical factors include the manner in which chemical reactions play a part in friction and wear behavior. Under rubbing contact, chemical reactivity and kinetics are known to change. The formation of acids in lubricants can accelerate wear. Reactivity varies strongly with temperature. Engine materials can dissolve in fuels and lubricants, changing their chemistry over time. Deposits, like carbon, build up on contact surfaces.

1.1.3 Lubrication factors include identifying the appropriate regime(s) of lubrication experienced by the components of interest and the degree to which the laboratory test must replicate that/those regime(s). Lubricants also serve to remove heat and harmful particles. A simulation should replicate the regime of lubrication and account for the changes in viscosity of the lubricant during the operating cycle. 
1.1.4 Materials factors involve the composition, processing, and microstructures of the materials that must be lubricated or protected from wear. Surface treatments and coatings are used to protect materials if full separation by the lubricant cannot be ensured.

1.1.5 Third bodies are particles that affect wear or lubrication. Three-body wear is, in fact, a form of abrasive wear in which loose particles in the interface between bodies result in the progressive loose of surface material. The sources of third bodies include dust from the environment, wear particles, sand left over from engine block casting operations, and soot particle agglomerates that happen to get entrained in the lubricant. Simulating third body effects is challenging because their effects have to be balanced with the other influences affecting the dominant wear mode.

1.1.6 Thermal factors include the generation and dissipation of heat in the engine components. Among other things, temperature affects the tribochemistry of the lubricant and its ability to support the contact pressure (viscosity). Much of the wear of engines is generated when the engine is cold, at start-up, so wear should not be assumed to be a linear function of operating time. Rather the instantaneous wear rate is expected to change significantly over the course of an engine's useful lifetime.

1.1.7 The Human Factor. Arguably the most important, yet uncontrolled, variable to be addressed in seeking a correlation between laboratory results and field performance is the human factor. Designers have a difficult time accounting for the whims and eccentricities of the driver and the use to which a vehicle is put once it leaves the dealer's control. The author of a popular paperback book puts it this way:

"Anyone can drive a car for 200,000 miles if the engine and transmission are rebuilt every 75,000 miles. There's no trick to that. But there is a trick to driving 200,000 miles without a major repair."

Bob Sikorsky (1997)

Drive It Forever, ATG Media.

The influence of human factors is manifested in three ways:

1. The driving profile and operating environment for the vehicle. This includes things like the average length of each trip, the number of trips per day, and the part of the country that the vehicle operates in (ambient temperature, weather conditions, and topography).

2. Operator technique. This includes aspects like the aggressiveness of the driver, the driver's tendency for rapid accelerations and decelerations, and whether the driver warms up or idles the vehicle before starting to drive.

3. Care and maintenance practices. This includes oil change intervals, expertise of the person conducting engine repairs, engine adjustments, and related factors. If a vehicle is driven for long distances (compared with frequent short trips), when wear rate is least severe, the oil change interval can be extended. 
Appendix A, compiled from two recent reviews, lists the scientific and engineering factors involved in simulations in greater detail.

\subsection{Levels of Testing Scale}

The German standard DIN 50322 lists six levels of tribotesting that range from field trials (Level I) to simple specimen coupon tests (Level VI). This system can be further simplified into five levels as follows:

\section{Level A. Vehicle on- and/or off-road tests}

Level B. Full-size dynamometer test stand (entire vehicle)

Level C. Full-scale engine tests (engine test cells)

Level D. Sub-assembly tests (full-scale mating parts)

Level E. Coupon tests (sub-scale tests, part sections or simple coupons)

The cost per test tends to increase from Level E to A, but the degree to which the test variables can be controlled tends to increase in the opposite direction.

The primary concern in developing and using Level D and E tests to select materials and lubricants is to establish a direct engineering linkage to Level A performance. It is possible that an intermediate level of correlation will be necessary. For example, it may be possible to correlate Level E to Level C and Level C to Level A. Correlation issues comprise the focus of this review.

When reviewing the literature of laboratory simulations of ring and liner performance, seven basic considerations were kept in mind:

\begin{tabular}{|l|l|l|}
\hline \multicolumn{1}{|c|}{ Consideration } & \multicolumn{1}{|c|}{ Level A - Performance } & \multicolumn{1}{c|}{ Level E - Performance } \\
\hline \hline Contact stress level & $\begin{array}{l}\text { difficult to measure in running engines; } \\
\text { often calculated based on geometric and } \\
\text { operating assumptions; varies with time } \\
\text { and wear-in; may vary from engine to } \\
\text { engine and cylinder to cylinder }\end{array}$ & $\begin{array}{l}\text { generally easy to control in laboratory } \\
\text { testing systems; conformal contact } \\
\text { enables constant stress; counterformal } \\
\text { contact generally produces decreasing } \\
\text { stress with time due to wear }\end{array}$ \\
\hline Heat flow & $\begin{array}{l}\text { depends on engine configuration and } \\
\text { cooling system; varies during start-up; } \\
\text { may vary from cylinder-to-cylinder; } \\
\text { affects internal stresses from differential } \\
\text { thermal expansion of adjacent parts }\end{array}$ & $\begin{array}{l}\text { tends to reach a steady state condition } \\
\text { and is repeatable from test to test }\end{array}$ \\
\hline Residual stress level & $\begin{array}{l}\text { varies with the assembly procedure and } \\
\text { heat treatment of the part; residual stress } \\
\text { distributions exist in cast and wrought } \\
\text { parts; difficult to measure in full-size } \\
\text { parts (neutron-based methods) }\end{array}$ & difficult to simulate in the laboratory \\
\hline Part alignment & $\begin{array}{l}\text { can have significant effect on wear } \\
\text { pattern and friction during start-up and } \\
\text { running-in }\end{array}$ & $\begin{array}{l}\text { affects the repeatability of results, affects } \\
\text { uniformity of contact stress, important } \\
\text { effects in conformal testing }\end{array}$ \\
\hline Surface features & critical for identifying the dominant & an important indication of the accuracy of \\
\hline
\end{tabular}




\begin{tabular}{|l|l|l|}
\hline & $\begin{array}{l}\text { form(s) of wear; can be hidden by } \\
\text { deposits or lubricant residues }\end{array}$ & the simulated wear behavior \\
\hline Lubricant degradation & $\begin{array}{l}\text { oxidation and contamination with water } \\
\text { and fuel changes behavior; lubricant } \\
\text { residence time in hot areas can trigger } \\
\text { changes; lubricant properties in the } \\
\text { sump are not the same as those in the } \\
\text { ring-liner contact zone; oil changes }\end{array}$ & $\begin{array}{l}\text { difficult to simulate correctly in the } \\
\text { laboratory; difficult to duplicate the form } \\
\text { of soot, fuel residues, wear debris, and } \\
\text { water build-up }\end{array}$ \\
\hline $\begin{array}{l}\text { Constancy of } \\
\text { conditions }\end{array}$ & $\begin{array}{l}\text { field use produces a wide range of } \\
\text { variable operating conditions; even } \\
\text { relatively tight test protocols are difficult } \\
\text { to reproduce exactly due to weather, } \\
\text { road conditions, traffic, etc. }\end{array}$ & $\begin{array}{l}\text { most often run under constant operating } \\
\text { conditions; the development of complex } \\
\text { protocols involving variable loads, } \\
\text { speeds, temperatures, start/stop, and } \\
\text { changing oil conditions is rarely if ever } \\
\text { done at this level of testing }\end{array}$ \\
\hline
\end{tabular}

\subsection{Annotated Literature Review of Ring/Cylinder Bore Studies}

Information for this review was gleaned from a variety of sources. Each citation briefly summarizes the approach taken when producing the simulation. Only a small number of these studies compared the results of their work with similar materials or lubricant performance in fired engines. That made it difficult to assess the validity of the simulation. In most cases, only a few of the aspects of the engine environment were matched in the design of sub-scale tests. Such features as piston ring/cylinder alignment during engine assembly, and cylinder-to-cylinder variations in running engines were not generally considered in laboratory simulations.

The following standard format was selected for this review to facilitate the comparison of published studies.

[Ref \#] Author(s)

Title of Publication

Components being simulated

Applied load or contact pressure

Applied motion

Applied contact speed

Materials/surface treatments

Lubricant(s)

Correlation of results with actual components (if any)

Other comments or discussion:
Publication details - date, volume, etc.

Level of Simulation $(A, B, C, D \text { or } E)^{*}$

Rationale for selection

Rationale for selection

Rationale for selection

Test temperature/environment

* see listing and description in Section 1.2

\section{Summary List of References that are Outlined in the Following Section:}

[1] R. J. Sloan, U.S. patent \# 5,007,284 (1991)

[2] G. F. Al-Khalidi and T. S. Eyre, Tribology International (1987) Vol. 20 (1), 18-24

[3] K. F. Dufrane and W. A. GlaeserProc. Intl. Conf. on Wear of Matl's (1987), ASME, pp. 285-291.

[4] K. F. Dufrane, W. A. Glaeser, and A. R. Rosenfeld, Report (1988) ORNL/Sub/84-00216/1

[5] S. E. Hartfield-Wunsch, S. C. Tung, and C. J. Rivard, SAE Technical paper (1993) \# 932693. 
[6] G. C. Barber and K. C. Ludema Wear (1987) Vol 118, pp. 57-75

[7] M. G. S. Naylor, Oak Ridge National Laboratory Technical Report (1992) ORNL/Sub/87-SA581/1

[8] M. P. Volarovich, Wear (1958/9) Vol. 2, pp. 203-216.

[9] E. Wacker, Metallurgical Aspects of Wear (1979), pub. by DGM E.V., pp. 247-267

[10] D. J. Patterson, S. H. Hill and S. C. Tung, Lubrication Engineering (1993), February, pp. 89-95.

[11] S. Venkatesh, Wear (1973), Vol. 25, pp. 65-71

[12] S. H. Hill, S. E. Hartfield-W Jnsch, and S. C. Tung (1996), Tribology Trans., Vol. 39 (4), 929-935.

[13] V. D. N. Rao, D. M. Kabat, D. Yeager, and B. Lizotte, Concepts in New Engine and Component Design, SAE Special Pub. SP-1225 (1997); also SAE Paper 97009.

[14] V. D. N. Rao, D. M. Kabat, R. Rose, D. Yeager, R. Brandt, and D. Y. Leong, SAE Paper (1997) SAE 970008

[15] V. D. N. Rao, D. M. Kabat, H. A. Cikanek, C. A. Fuinari, and G. Wuest, SAE Paper (1997)

SAE 970023 (in Applications for Aluminum in Vehicle Design, SAE Spec Pub-1251)

[16] P. I. Lacey and R. T. Stockwell (1999) Tribology Trans., Vol. 42 (1), 192-201.

\section{Annotated Reference List:}

[1] Ralph J. Sloan

U.S. patent \# 5,007,284 (1991)

\section{Piston Ring and Liner Wear Simulator and Method of Using Same}

piston ring and cylinder liner wear

pneumatic pressure - variable*

Reciprocating motion

Applied contact speed

Materials/surface treatments

Lubrication: none or engine oil

Level $\mathrm{E}$ - piston rings and liner segments

up to $\sim 650 \mathrm{~N}$ to sim. turboch. diesel ring loads

same as ring-on-liner motion

up to $700 \mathrm{rpm}$ (limited by inertia of apparatus)

various plated/coated rings and grey cast iron liners

$\mathrm{T}$ up to $550^{\circ} \mathrm{C}$ (max. for advanced diesels)

Correlation with Cummins V-903 production engine, un-cooled Cummins NTC 250 engine

Other comments: Instrumented with crank angle and friction force measurements. Other data comparisons were with Cameron-Plint TE-77 reciprocating tester to check ability to discriminate between oils. *Typical load: $125 \mathrm{~N} / \mathrm{cm}$ of ring width.

Sample test results:

Sloan machine data:

\begin{tabular}{|l|l|c|c|c|c|c|c|}
\hline \multicolumn{1}{|c|}{ Ring Material } & \multicolumn{1}{|c|}{ Liner Material } & $\begin{array}{c}\text { Load } \\
(\mathrm{N} / \mathrm{mm})\end{array}$ & $\begin{array}{c}\text { Speed, } \\
\text { Test time } \\
(\mathrm{rpm}, \mathrm{h})\end{array}$ & $\begin{array}{c}\text { Temper- } \\
\text { ature }(\mathrm{C})\end{array}$ & $\begin{array}{c}\text { Lubricant, } \\
\text { supply rate } \\
(\mathrm{m} / \mathrm{h})\end{array}$ & $\begin{array}{c}\text { Friction } \\
\text { Coefficient }\end{array}$ & $\begin{array}{c}\text { Liner Wear } \\
\text { Rate } \\
(\mathrm{mm} 3 / \mathrm{N}-\mathrm{m})\end{array}$ \\
\hline Cr-plate & grey cast iron & 124 & 266,2 & 25 & mineral oil, 1 & 0.05 & $1.9 \times 10^{-6}$ \\
\hline $\mathrm{PI}$. Spray $\mathrm{Cr}_{2} \mathrm{O}_{3}$ & $\mathrm{Pl}$. Spray $\mathrm{Cr}_{2} \mathrm{O}_{3}$ & 124 & 266,2 & 427 & none & 0.55 & $<3 \times 10^{-7}$ \\
\hline $\mathrm{TiC} / \mathrm{CaF}_{2}$ coating & $\mathrm{Cr}_{3} \mathrm{C}_{2}$ coating & 124 & 266,2 & 427 & none & 0.58 & $4.5 \times 10^{-5}$ \\
\hline
\end{tabular}

Cameron Plint machine data:

\begin{tabular}{|l|l|c|c|c|c|c|c|}
\hline \multicolumn{1}{|c|}{ Ring Material } & Liner Material & $\begin{array}{c}\text { Load } \\
(\mathrm{N} / \mathrm{mm})\end{array}$ & $\begin{array}{c}\text { Speed } \\
(\mathrm{rpm})\end{array}$ & $\begin{array}{c}\text { Temper- } \\
\text { ature }(\mathrm{C})\end{array}$ & $\begin{array}{c}\text { Lubricant } \\
\text { (in tray) }\end{array}$ & $\begin{array}{c}\text { Friction } \\
\text { Coefficient }\end{array}$ & $\begin{array}{c}\text { Liner Wear } \\
\text { Rate } \\
(\mathrm{mm} / \mathrm{N} / \mathrm{N}-\mathrm{m})\end{array}$ \\
\hline Cr-plate & grey cast iron & 8 & 600 & 25 & mineral oil & 0.16 & $2.3 \times 10^{-6}$ \\
\hline $\mathrm{Cr}$-plate & grey cast iron & 20 & 1200 & 25 & mineral oil & 0.06 & $1.4 \times 10^{-8}$ \\
\hline $\mathrm{TiC}_{\mathrm{CaF}}$ coating & $\mathrm{Cr}_{3} \mathrm{C}_{2}$ coating & 20 & 360 & 360 & none & 1.45 & $1.9 \times 10^{-5}$ \\
\hline
\end{tabular}

[2] G. F. Al-Khalidi and T. S. Eyre Tribology International (1987) Vol. 20 (1), 18-24

\section{Bore-polishing - identification and simulation}

cylinder bores of diesel engines

Level $\mathrm{E}$ - piston ring segment on liner segement 
Load: $300-1500 \mathrm{~N}$ in $300 \mathrm{~N}$ increments not given

Reciprocating motion

piston on liner motion

$8.3 \mathrm{cycles} / \mathrm{min}$ for up to $20 \mathrm{~h}$

not given

Materials/surface treatments

Two oils - one promoting bore polish. $80^{\circ} \mathrm{C}$ constant immersion

Correlation with actual components: Observed features similar to those in a 'Tornado' diesel engine.

Other comments: Characteristics of bore polishing features in a Tornado diesel engine: 'light polish' = mirror finish overlaid on the honing pattern $(\mathrm{Ra}=0.55 \mu \mathrm{m})$, 'medium polish' = mirror finish showing faint original honing pattern $(\mathrm{Ra}=0.15 \mu \mathrm{m})$, 'heavy polish' = mirror finish with no traces of the original honing pattern $(\mathrm{Ra}=0.08 \mu \mathrm{m})$

[3] K. F. Dufrane and W. A. Glaeser

Proc. Intl. Conf. on Wear of Matl's (1987), ASME, pp. 285-291.

\section{Wear of Ceramics In Advanced Heat Engine Applications}

Rings and liners

Up to $7.7 \mathrm{~N} / \mathrm{mm}$

Reciprocating cylinders on flats

Speeds 500-1000 rpm for $1.5 \mathrm{hr}$

Series of self-mated monolithic ceramics

Dry and with SAE $10 \mathrm{~W}$ oil $\quad 290-540^{\circ} \mathrm{C}$ with diesel exhaust blown through

Correlation with actual components: not given, except for reference to 'typical' value of the wear coefficient for a Cr-plated ring on cast iron.

Selected data follow:

\begin{tabular}{|c|c|c|c|c|}
\hline 'Ring' Material & 'Cylinder' Material & Lubricant & $\begin{array}{c}\text { Test } \\
\text { Temperature } \\
\text { (C) }\end{array}$ & $\begin{array}{l}\text { 'Ring' Wear Coefficient, k } \\
\text { (dimensionless) }\end{array}$ \\
\hline $\mathrm{Cr}$ & cast iron & SAE 30 & 100 & $5 \times 10^{-9}$ reference $^{*}$ \\
\hline $\mathrm{Cr}$ & cast iron & SAE 10W SF/CC & 20 & $2 \times 10^{-6}$ \\
\hline $\mathrm{SiC}$ & SiC & none & 20 & fracture - no measurement \\
\hline $\mathrm{SiC}$ & $\mathrm{SiC}$ & SAE 10W SF/CC & 20 & $3 \times 10^{-6}$ \\
\hline $\mathrm{Si}_{3} \mathrm{~N}_{4}$ & $\mathrm{Si}_{3} \mathrm{~N}_{4}$ & none & 20 & $9 \times 10^{-4}$ \\
\hline $\mathrm{Si}_{3} \mathrm{~N}_{4}$ & $\mathrm{Si}_{3} \mathrm{~N}_{4}$ & SAE 10W SF/CC & 20 & $2 \times 10^{-6}$ \\
\hline YPSZ & YPSZ & none & 20 & $8 \times 10^{-4}$ \\
\hline YPSZ & YPSZ & SAE 10W SF/CC & 20 & $2 \times 10^{-4}$ \\
\hline
\end{tabular}

" Authors claim to be "typical diesel truck engine experience"

[4] K. F. Dufrane, W. A. Glaeser, and A. R. Rosenfeld Report (1988) ORNL/Sub/84-00216/1

\section{Studies of Dynamic Contact of Ceramics and Alloys for Heat Engines}

Rings and liners

Up to $950 \mathrm{~N}$, up to $50 \mathrm{~N} / \mathrm{mm}$

Reciprocating cylinders on flats

Speeds 500-1000 rpm for $1.5 \mathrm{hr}$

Series of self-mated monolithic ceramics

Dry and with poly-alphaolefin oil most tests at $260^{\circ} \mathrm{C}$ with diesel exhaust blown through

Correlation with actual components: not given, except for reference to 'typical' value of the wear coefficient for a Cr-plated ring on cast iron.

Other comments: More detailed version of Ref \# Contains additional friction and wear data. 
[5] S. E. Hartfield-Wunsch, S. C. Tung, and C. J. Rivard SAE Technical paper (1993) \# 932693.

Development of a Bench Wear Test for the Evaluation of Engine Cylinder Components and the Correlation with Engine Test Results

Ring/cylinder bore

$80 \mathrm{~N}(7 \mathrm{MPa})$

Reciprocating motion

$600 \mathrm{rpm}, 10 \mathrm{~mm}$ stroke, $5 \mathrm{hrs}$

Level E - ring segment and bore segment

intended to represent typical pressure; scar width $\mathrm{x}$ ring width

similar to piston and bore

Thermally-spray modified aluminum alloy liners, cast iron (baseline), $\mathrm{Cr}$ and Mo plated rings.

SAE 5W-30 API SG oil Temperature $120^{\circ} \mathrm{C}$ to minimize oil degradation.

Correlation with actual components: compared results to a $200 \mathrm{hr}, 4$ cylinder engine dynamometer test.

Other comments: Thermal sprayed coating materials were not well described - only as " $A, B$, $C$, and

D", so it was not possible to correlate results with composition.

The following comparative wear test rankings were obtained:

\begin{tabular}{|c||c|c||c|c|}
\hline Alloy & $\begin{array}{c}\text { Bench Test } \\
\text { Average Wear } \\
\text { Depth }(\mu \mathrm{m})\end{array}$ & $\begin{array}{c}\text { Bench Test } \\
\text { Wear Ranking } \\
(1=\text { best })\end{array}$ & $\begin{array}{c}\text { Engine Test } \\
\text { Average Wear } \\
\text { Depth }(\mu \mathrm{m})\end{array}$ & $\begin{array}{c}\text { Engine Test } \\
\text { Wear Ranking } \\
(1=\text { best })\end{array}$ \\
\hline \hline A & 5.2 & 1 & 6.0 & 1 \\
\hline B & 24.1 & 4 & 15.0 & 4 \\
\hline C & 6.1 & 2 & 8.5 & 3 \\
\hline D & 12.1 & 3 & 8.0 & 2 \\
\hline
\end{tabular}

[6] G. C. Barber and K. C. Ludema Wear (1987) Vol 118, pp. 57-75

The Break-in Stage of Cylinder-Ring Wear: A Correlation between Fired Engines and a Laboratory Simulator

Piston ring/cylinder wall

Applied load or contact pressure

Level $\mathrm{E}$ - ring segment on cylinder segment

Reciprocating, slider crank

Rationale for selection

$350 \mathrm{cycles} / \mathrm{min} \times 19 \mathrm{~mm}$ stroke speed within the capabilities of the test machine

Materials/surface treatments: Mo-filled Cadillac top rings on coarse pearlitic cast-Fe.

Lubricant: $0.04 \mathrm{ml}$ drip at 3 min interv. Room temperature

Correlation with actual components: Examined 18 cylinder liners taken from fired Cadillac and Chevrolet engines. Engine run time from $20 \mathrm{~min}$ to 94,000 miles. Claimed damage features very similar in simulated and fired engine.

Other comments: No observable surface damage below contact pressures of $100 \mathrm{kPa}$.

[7] M. G. S. Naylor

Report (1992) ORNL/Sub/87-SA581/1

Development of Wear-Resistant Coatings for Diesel Engine Components

ring/liner

Level E - cylinder-on-flat (Cameron Plint machine)

$225 \mathrm{~N}$ on $7.5 \mathrm{~mm}$ ring $(30 \mathrm{~N} / \mathrm{mm})$

Reciprocating, $5 \mathrm{~mm}$ stroke

$20 \mathrm{~Hz}$

typical max. heavy-duty diesel ring load at top-dead-center

reciprocating ring in bore

not given

Materials/surface treatments: various ring coatings on several types of 'cylinder' materials

Lubricant(s): fresh oil, 3.3\% C sooty oil (2 kinds), PAO lubricant, and nonlubricated, and $\mathrm{T}=200-450^{\circ} \mathrm{C}$

Correlation with actual components: used practical operating conditions

Other comments: Average wear rates for 4 tests using Cr-plated ring material on a pearlitic cast iron cylinder material at $350^{\circ} \mathrm{C}$ in fresh $15 \mathrm{~W} 40$ mineral oil:

\begin{tabular}{|l|l|}
\hline Ring wear rate & $1.12 \times 10^{-7} \mathrm{~mm} 3 / \mathrm{N}-\mathrm{m}$ \\
\hline
\end{tabular}




\begin{tabular}{|l|l|}
\hline Liner wear rate & $8.39 \times 10^{-6} \mathrm{~mm}^{3} / \mathrm{N}-\mathrm{m}$ \\
\hline friction coefficient & 0.12 \\
\hline
\end{tabular}

There was a significant effect of used versus new oil.

[8] M. P. Volarovich

Wear (1958/9) Vol. 2, pp. 203-216.

\section{An Investigation of Piston-Cylinder and Shaft Bearing Friction at Low Temperatures}

Piston/liner, shaft bearing Level $\mathrm{D}$ - piston in a piston sleeve

Apparatus designed to apply various shear forces Rationale: study lubricant properties

Reciprocating motion

Simulate piston motion

Applied contact speed not given

Materials/surface treatments: standard ring and liner materials not described

Lubricant(s): variety with different viscosities Test temperatures down to $-60^{\circ} \mathrm{C}$

Correlation with actual components: not done

Other comments: This study was designed to examine the effects of lubricant thickening at cold temperatures on the starting friction of engines. The experimental conditions of the work were poorly documented.

[9] E. Wacker

Metall. Aspects of Wear (1979), pub. by DGM E.V., pp. 247-267.

The Use of a Testing Machine for Simulating Piston Ring Groove Wear

Ring in the piston's upper ring groove Level $\mathrm{E}$ - articulating specimen in multi-axis machine

Normal pressure 50-70 bar (0.725-1 ksi) Rationale for selection: truck diesel motor typ. pressure

Applied motion- complex multi-axis motions Simulate closely a ring's complex motions in its groove

Applied contact speed 1600-2650 rpm Rationale for selection: typical diesel engine speed

Materials: comparison of austenitic cast iron to $\mathrm{Al}-12 \% \mathrm{Si}$ alloy piston materials

Lubricant(s): not given

Test temperatures $200-250^{\circ} \mathrm{C}$

Correlation with actual components: (see Other comments, below)

Other comments:

(1) The ratio of the wear rates for the fired diesel engine: Al-Si: cast Fe was about a factor of 3.

In lab tests, the ratio of $\mathrm{Al}-\mathrm{Si}$ wear to cast Fe wear could be adjusted by changing the frequency and contact pressure to approach the same ratio. But the wear rates per $\mathrm{mm}$ of sliding distance were much higher in the lab (50-100 X) compared with the actual engine.

(2) Background wear data from fired engines (Piston material = Niresist austenitic cast iron)

\begin{tabular}{|l|c|c|}
\hline & $\begin{array}{c}\text { 4-stroke truck } \\
\text { diesel engine }\end{array}$ & $\begin{array}{c}\text { 4-stroke car } \\
\text { diesel engine }\end{array}$ \\
\hline Piston material & $\begin{array}{c}\text { Niresist austenitic } \\
\text { cast iron }\end{array}$ & Al-12\%Si alloy \\
\hline $\begin{array}{l}\text { Max. wear of upper face of the upper ring groove } \\
(\mathrm{mm} / 100 \mathrm{hr})\end{array}$ & $0.005-0.012$ & $0.08-0.20$ \\
\hline Max. wear of lower face of the upper ring groove $(\mathrm{mm})$ & $0.004-0.015$ & \\
\hline
\end{tabular}

(3) It was noted that the corrosion and abrasive effects were not well known and difficult to simulate. Studies indicated that the wear of the groove face was increased with dust in the oil (up to $200 \mathrm{ppm}$ ).

[10] D. J. Patterson, S. H. Hill and S. C. Tung Lubrication Engineering (1993), February, pp. 89-95.

Bench Wear Testing of Engine Power Cylinder Components

Ring/liner simulation

Level D/E - 3 bench methods compared 
(1) Unidirectional sliding. LFW-1 block-on-ring machine, incremental loading 133-534 N, 197 rpm (0.36 $\mathrm{m} / \mathrm{s}$ ), lubricant SAE $20 \mathrm{~W}$ oil at $90-93^{\circ} \mathrm{C}$, conditions selected for accelerated testing. (Level E)

(2) Reciprocating sliding, Cameron-Plint TE-77 machine, 80-120 N load corresponding to 900-1300 psi cylinder pressure, $10-40 \mathrm{~Hz}$ with 7.5 and $10 \mathrm{~mm}$ stroke, 60 or $120 \mathrm{hrs}$, SAE 5W-30 or 20W-20 oil at $150^{\circ}$ C. Used undersized ring to avoid edge contact (Level D)

(3) Reciprocating sliding EMA-LS9 machine (similar to Sloan machine see Ref. [1]), load $288 \mathrm{~N}$, speed 500-700 cycles/min, AMOCO 300 oil at $149^{\circ} \mathrm{C}$ delivered at $1 \mathrm{ml} / \mathrm{hr}$, test duration $20 \mathrm{hrs}$ typ.

Correlation with actual components: Machine 1 and Machine 3 data for three different ring coatings were correlated with tests run on a engine dynamometer with both spark ignition and diesel engines.

\begin{tabular}{|l|c|c|}
\hline & $\begin{array}{c}\text { Correlation } \mathrm{R}^{2}(\%) \\
\text { Diesel Engine }\end{array}$ & $\begin{array}{c}\text { Correlation } \mathrm{R}^{2}(\%) \\
\text { Spark Ignition }\end{array}$ \\
\hline LFW -1 & 92 & 76 \\
\hline EMA-LS9 & 99 & 90 \\
\hline
\end{tabular}

[11] S. Venkatesh

Wear (1973), Vol. 25, pp. 65-71

Surface Treatments for Pistons and their Effect on Engine Performance

Diesel piston

No stated contact pressure

Reciprocating motion

Applied contact speed: $1500 \mathrm{rpm}$

Level C - single-cylinder 4-stroke diesel

Dictated by operating conditions

Dictated by engine design

Selected speed

Lubricant(s): not given

Al alloy piston, phosphated, various types of anodizing
Test temperature: maintained oil temperature at $80^{\circ} \mathrm{C}$

Other comments: Wear and friction not measured directly although there were observations on the appearance of the various surface treatments after exposure.

[12] S. H. Hill, S. E. Hartfield-W $\int n s c h$, and S. C. Tung

Tribology Trans. (1996) Vol. 39 (4), 929-935.

Bench Wear Testing of Common Gasoline Engine Cylinder Bore Surface/Piston Ring

Combinations

Ring/cylinder bore

Test conditions for each machine:

Level $\mathrm{E}$ - ring section on liner section (2 machines)

(1) Reciprocating sliding. Cameron-Plint TE-77 machine, $80 \mathrm{~N}$ load, $10 \mathrm{~Hz}$ with $10 \mathrm{~mm}$ stroke, $40 \mathrm{hrs}$, SAE 5W-30 oil at $120^{\circ} \mathrm{C}$. Used undersized ring to avoid edge contact (Level D)

(2) Reciprocating sliding EMA-LS9 machine (similar to Sloan machine see Ref. [1]), load 72 N, speed 500 cycles/min with a $25 \mathrm{~mm}$ stroke length, SAE $5 \mathrm{~W}-30$ oil at $165^{\circ} \mathrm{C}$ delivered at $1 \mathrm{ml} / \mathrm{hr}$, test duration $30 \mathrm{hrs}$.

Materials/surface treatments: Rings: Cr-plated, Mo-plated, gas nitrided stainless steel; bores: cast iron, Al-Si C390 alloy, Nikasil plated liners

Correlation with actual components: not done

Other comments: Ring wear results varied more between the two machines than the bore segment wear. With ring wear, there was no apparent bias - that is some results were higher on one machine and others higher on the other. There seemed to be a better more consistent ranking of wear for the bore segments, even thought results were not the same quantitatively between the two machines.

[13] V. D. N. Rao, D. M. Kabat, D. Yeager, and B. Lizotte Concepts in New Engine and Component Design, SAE Special Pub. SP-1225 (1997); also SAE Paper 970009,

\section{Engine Studies of Solid Film Lubricant Coated Pistons}

Piston skirt surfaces

Levels $\mathrm{D}$ and $\mathrm{C}$ (with follow-up at level A) 
Two testing machines:

1) Motored, single-cylinder test rig (level D)

Modified 4-stroke, using a 1.9L -CVH piston system motored rig with drop-in wet cylinder liners. Oil mist lubrication of the bore wall. Warm-up $1 \mathrm{hr}, 1000 \mathrm{rpm}$, stabilize coolant at $80^{\circ} \mathrm{C}$ and oil temperature at $65^{\circ}$ $\mathrm{C}$, measure torque through the range 500-1500 rpm with $10 \mathrm{~min}$ increments, and then 1500-500 rpm. Durability tests $=20 \mathrm{hrs}$ at $1500 \mathrm{rpm}$.

2) Fired engine in a dynamometer test cell (level $\mathrm{C}$ )

1992 model 1.9 I. CVH cast iron block, Al head, 5W30 oil. multi-stage break-in and running cycle.

Materials/surface treatments; various solid film lubricant coatings containing graphite, $\mathrm{MoS}_{2}$, and BN.

Correlation with fired engines: Used machine 1 to screen coatings for machine 2 . Those showing best results in the motored tests also performed well in the fired engine test. The leading film (epoxy based with $\mathrm{MoS}_{2}$, graphite and hexagonal BN solid lubricant additives) was used in vehicle tests for up to 51,000 miles.

[14] V. D. N. Rao, D. M. Kabat, R. Rose, D. Yeager, R. Brandt, and D. Y. Leong SAE Paper (1997) SAE 970008

Performance of Plasmaspray Coated Bore 4.6L-V8 Aluminum Block Engines in Dynamometer and Fleet vehicle Durability Tests

Cylinder bores

Level of Simulation $(C$ and $A)$

Break-in: 850 rpm idle (1 hr), 1500 rpm (2 hr), 2000 rpm wide open throttle (1) hr; followed by $100 \mathrm{hr}$ test.

Materials/surface treatments: Aluminum cylinder bores and Al sleeves, plasma-sprayed coatings of iron oxide base and with $\mathrm{BN}$ additives

Correlation of results with actual components: Both test cell and fleet tests were conducted.

Comments: Complex combinations of test conditions made it impossible to directly compare results of test cell runs with fleet tests. The primary emphasis was in down-selecting coatings in the dynamometer tests and using fleet tests to verify results, albeit with different metrics.

[15] V. D. N. Rao, D. M. Kabat, H. A. Cikanek, C. A. Fuinari, and G. Wuest SAE Paper (1997)

SAE 970023 (in Applications for Aluminum in Vehicle Design. SAE Spec Pub-1251)

Material Systems for Cylinder Bore Applications - Plasma Spray Technology

Cylinder bore

Level D

Test conditions (see Ref \{13], Machine 1)

Materials/surface treatments; 14 different plasma sprayed coatings

Other comments or discussion: Results were also compared with scuffing tests using the LS9 (Sloan) machine. The LS-9 data were said to produce scuffing effects due to dominant boundary regime lubrication, but the motored rig was said to produce not only boundary lubrication, but because of its longer stroke, mixed film as well.

[16] P. I. Lacey and R. T. Stockwell

Tribology Transactions, Vol. 42(1), 192-201

Development of a Methodology to Predict Cylinder Liner Scuffing in the 6V92TA Engine Lubricant Test

Cylinder bore Level E - (with correlation to Level C)

Test conditions: Two laboratory tests were compared with engine results and lubricant volatility tests

1) 4-ball lubricant test - in accordance with ASTM D-4172 (for wear resistance of a lubricant) and ASTM

D-2783 (load-carrying capacity of a lubricant). Wear resistance is given as average wear scar diameter on the 3 fixed balls. 
2) Block-on-ring sliding wear - ( as described in ASTM D-2714, "LFW-1" machine) Modified spindle speed for $1200 \mathrm{rpm}(2.20 \mathrm{~m} / \mathrm{s})$, normal load $270 \mathrm{kgf}$, wear scar width used as a measure of wear.

Lubricants: 25 commercial crankcase lubricants were evaluate in type 6V92TA or 6V53T engines.

Other comments or discussion: Most commercial diesels operate with a top ring reversal point temperature of $180-200^{\circ} \mathrm{C}$. Typical steady state specific wear rates for liners should be in the range of $10^{-10}$ to $10^{-13} \mathrm{~mm}^{3} / \mathrm{N}-\underline{\mathrm{mm}}$ (i.e., equivalent to $10^{-7}$ to $10^{-10} \mathrm{~mm}^{3} / \mathrm{N}-\underline{\mathrm{m}}$ ). Minimum calculated oil film thickness at $2300 \mathrm{rpm}$ was $\sim 0.5 \mu \mathrm{m}$. Correlation of basic LFW-1 results with scuffing on actual liner 6V92TA was $\mathrm{R}^{2}=54 \%$. Inadequate to distinguish between best and worst oils. New test involves a parameter that combines LFW-1 results with lubricant boiling fraction to predict \% scuffing observed on an engine test. Ring and block surface finishes are designed to simulate a run-in condition, $600 \mathrm{rpm}(1.1 \mathrm{~m} / \mathrm{s}), 85^{\circ} \mathrm{C}, 20$ min, 90, 120, and $150 \mathrm{~kg}$ contact load, SAE 01 block and SAE 4620 steel ring. This improved the correlation $\mathrm{R}^{2}$ to $70 \%$.

\subsection{Conclusions and Recommendations}

\subsection{Conclusions}

There is clear evidence that most of the engine cylinder and ring wear occur when an engine is started up from a cold condition, and at the location on the stroke where the lubricant film is least well-established, at the hot end of the cylinder (top-dead-center). Despite this observation, investigators usually attempt to simulate steady-state (hot oil) running conditions in laboratory-scale tests. It seems prudent then to design accelerated ring/cylinder friction and wear tests under conditions that simulate cold, start-up conditions. Furthermore, the condition of the oil also affects component wear and friction. Therefore, even though the test conditions might be run 'cold,' the oil condition should also be degraded, as it would be after exposure to hot running and with increased abrasivity due to the degradation of anti-wear additives and soot).

A review of the technical literature was conducted in an attempt to establish the most promising approaches to simulating the friction and wear of diesel engine rings and cylinder bore friction and wear using laboratory-scale test methods. Correlations between bench-scale tests and full sized engine tests were rare or the descriptions incomplete. Sometimes qualitative observations were used instead of quantitative friction and wear measurements.

Laboratory-scale studies of materials and lubricants for piston ring lubrication have been conducted for decades, but the conditions are extremely varied and there is no evidence in the literature to suggest that serious attempts at standardizing such tests were made. Standardization requires significant attention to specifying test conditions, understanding the variability inherent in the test method, and establishing formats for reporting the data that enable a useful comparison. The two commercial testing machines that appear most often in such studies are the Sloan LS-9 machine and the Plint TE-77. ORNL has led the development of ASTM standard test method G-133 that uses the Plint TE-77 under lubricated conditions in hot oil (ball-on-flat). Modification of that method to use ring and liner segments is therefore recommended.

Lacking close similarity in bench-testing procedures and methods, it is practically impossible to conduct a meaningful quantitative comparison of friction and wear data throughout the tribology literature. Among the most useful were studies that conducted several types of tests 
and compared their results. The most meaningful comparisons were possible only in terms of relative rankings or observations that some materials and surface treatments perform relatively well in laboratory tests and engine tests. Even then, the materials usually differed in preparation and surface condition.

\subsection{Recommendations}

Based on a literature review and consideration of issues raised in discussions with colleagues, there seems to be an opportunity to aid the diesel and automotive engine development community in the area of testing standardization and the use of degraded oils in laboratory tests.

(1) Develop a new standard test procedure based on the current ASTM G-133 reciprocating test, but that uses ring and liner segments with degraded (or simulated degraded) oil under repeated cold start conditions.

(2) Formulate a basic lubricant composition that produces the effects of degraded oil when using standardized testing procedures. This may require such approaches as "cooking the

oil' and adding abrasives to simulate the effects of carbon soot on the removal of anti-wear additives. 


\section{Appendix A}

Factors Affecting Ring/Liner Tribology 


\section{Appendix A.}

\section{Factors Affecting Ring/Liner Tribology}

[Summary based on: (1) M. G. Naylor, P. Kodali, and J. C. Wang (2001) "Diesel Engine Wear," Chap. 33 in Modern Tribology Handbook, ed. B. Bhushan, CRC Press. and (2) D. E. Richardson (2000) "Review of Power Cylinder Friction for Diesel Engines", J. of Engineering for Gas Turbines and Power, Vol. 122, pp. 506-519.]

Key: $\mathbf{C}=$ controllable variable, $\mathbf{E}=$ primary influence of this aspect

\begin{tabular}{|c|c|c|c|c|c|c|}
\hline Aspect & 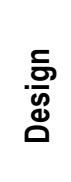 & 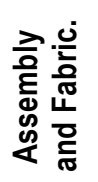 & 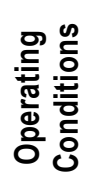 & 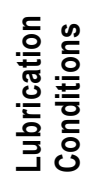 & 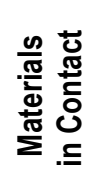 & Description of Effect(s) \\
\hline bore size & C & & & & & $\begin{array}{l}\text { minimal effect on ring/liner wear; contact } \\
\text { pressures tend to remain similar for different } \\
\text { sizes; friction power of rings and rods is } \\
\text { proportional to the bore size }\end{array}$ \\
\hline bore distortion & & C & & $E$ & $E$ & $\begin{array}{l}\text { excessive bore distortion can increase ring/liner } \\
\text { wear, also effects the lubricant film thickness } \\
\text { and its ability to support pressure }\end{array}$ \\
\hline stroke & C & & $E$ & $E$ & & $\begin{array}{l}\text { affects piston travel velocity and lubrication } \\
\text { regime; friction power of rings and rods is } \\
\text { proportional to (stroke)2 }\end{array}$ \\
\hline $\begin{array}{l}\text { connecting rod } \\
\text { length }\end{array}$ & C & & $\bar{E}$ & $\bar{E}$ & & $\begin{array}{l}\text { affects piston travel velocity and lubrication } \\
\text { regime }\end{array}$ \\
\hline $\begin{array}{l}\text { connecting rod } \\
\text { motion }\end{array}$ & C & & $E$ & & $\bar{E}$ & $\begin{array}{l}\text { rods constrained from moving along the axis of } \\
\text { the engine with the piston rather than between } \\
\text { crank throws; reduces friction }\end{array}$ \\
\hline cylinder pressure & C & & C & $\bar{E}$ & $\bar{E}$ & $\begin{array}{l}\text { higher pressure produces more engine load and } \\
\text { increased temperature which reduces oil } \\
\text { viscosity and film thickness, and leads to more } \\
\text { contact and more wear; high pressure can } \\
\text { increase radial pressure of ring on liner if the ring } \\
\text { width is relatively large (see "ring width" below); } \\
\text { gas pressure can also affect the retention of } \\
\text { lubricant between the ring and liner }\end{array}$ \\
\hline piston skirt design & C & $C$ & & $E$ & $E$ & minimize skirt to bore contact to reduce friction \\
\hline piston speed & & & C & $\bar{E}$ & $\mathrm{E}$ & $\begin{array}{l}\text { higher piston speed translates to more contact } \\
\text { cycles per unit time, but may also help reduce } \\
\text { wear because it facilitates hydrodynamic } \\
\text { lubrication; friction power of rings and rods } \\
\text { proportional to }(\mathrm{rpm})^{2} \text {, or as alternately derived, } \\
\text { to (piston velocity) }{ }^{1.5}\end{array}$ \\
\hline piston mass & C & & $\bar{E}$ & & & $\begin{array}{l}\text { less inertia and lower friction due to surface } \\
\text { contact force reduction }\end{array}$ \\
\hline $\begin{array}{l}\text { piston surface } \\
\text { treatments }\end{array}$ & C & & & & $\mathrm{C} / \mathrm{E}$ & $\begin{array}{l}\text { select surface treatments to enhance lubricity } \\
\text { and reduce wear; different approaches apply } \\
\text { depending on the type of wear and the location } \\
\text { on the piston }\end{array}$ \\
\hline $\begin{array}{l}\text { bore surface } \\
\text { treatments }\end{array}$ & C & & $\mathbf{E}$ & $E$ & C/E & $\begin{array}{l}\text { can reduce skirt and oil ring friction contributions } \\
\text { in the lower end of the bore }\end{array}$ \\
\hline
\end{tabular}




\begin{tabular}{|c|c|c|c|c|c|c|}
\hline liner finish & $C$ & $C$ & & $E$ & $E$ & $\begin{array}{l}\text { honing pattern and finish effects; discontinuous } \\
\text { honing marks or 'folded metal' can increase } \\
\text { wear }\end{array}$ \\
\hline ring - width & $C$ & & & $E$ & $E$ & $\begin{array}{l}\text { affects pressure exerted radially on the liner; } \\
\text { wider implies higher pressure on the wall; friction } \\
\text { power loss is proportional to (ring width) }\end{array}$ \\
\hline ring - profile & C & & $\bar{E}$ & $E$ & $\bar{E}$ & $\begin{array}{l}\text { affects net gas pressure and lubrication regime, } \\
\text { must be optimized for given engine to decrease } \\
\text { wear; ring profile effects enter into calculations } \\
\text { as adjustments to empirical constants; some } \\
\text { advantages in friction using barrel or skewed } \\
\text { barrel profiles; barrel profiles can also shift the } \\
\text { position of the friction peak in the friction versus } \\
\text { crank-angle plot }\end{array}$ \\
\hline $\begin{array}{l}\text { ring - cross- } \\
\text { section }\end{array}$ & C & & & $E$ & $E$ & $\begin{array}{l}\text { reduction in cross-section can reduce friction } \\
\text { loss by reducing the peak friction force on the } \\
\text { top ring }\end{array}$ \\
\hline ring - tension & C & & & & & $\begin{array}{l}\text { lower tension can make ring more conformable } \\
\text { and reduce friction }\end{array}$ \\
\hline ring - materials & & & & $E$ & $\mathrm{C} / \mathrm{E}$ & $\begin{array}{l}\text { can increase or decrease wear of the bore; can } \\
\text { affect running-in; can affect conformity of sliding } \\
\text { contact and oil film thickness }\end{array}$ \\
\hline $\begin{array}{l}\text { piston ring land } \\
\text { clearance }\end{array}$ & $C$ & & $E$ & $E$ & $E$ & $\begin{array}{l}\text { affects flow of gases through the ring pack which } \\
\text { affects ring forces and ultimately wear; too much } \\
\text { clearance can allow carbon deposits to form and } \\
\text { liner bore polishing to occur }\end{array}$ \\
\hline $\begin{array}{l}\text { piston ring groove } \\
\text { clearance }\end{array}$ & $C$ & & $E$ & $E$ & $E$ & $\begin{array}{l}\text { large clearances may lead to ring breakage, but } \\
\text { small clearances may lead to scuffing and } \\
\text { sticking (see also "piston ring land clearance") }\end{array}$ \\
\hline $\begin{array}{l}\text { number of } \\
\text { cylinders }\end{array}$ & $C$ & & & & $E$ & $\begin{array}{l}\text { friction power (loss) is linearly proportional to the } \\
\text { number of cylinders }\end{array}$ \\
\hline temperature & C & & C & $\mathrm{E}$ & $\mathrm{E}$ & $\begin{array}{l}\text { affected by cooling system design and engine } \\
\text { operating variables; affects oil viscosity and film } \\
\text { thickness, affects lubricant stability/degradation; } \\
\text { affects deposit formation; most of these effects } \\
\text { lead to increased liner/ring wear; lower } \\
\text { temperatures can lead to more sulphuric and } \\
\text { sulphurous acid condensation and hence, } \\
\text { corrosive attack, in higher } S \text { fuels }\end{array}$ \\
\hline $\begin{array}{l}\text { fuel - sulfiur } \\
\text { content }\end{array}$ & $C$ & & $\mathrm{C}$ & $E$ & $E$ & $\begin{array}{l}\text { high } S \text { can lead to acid formation and attack of } \\
\text { liner surfaces; reducing } S \text { in fuels suppresses } \\
\text { the corrosive attack; reducing } S \text { also reduces } \\
\text { fuel lubricity which creates wear problems. }\end{array}$ \\
\hline fuel - combustion & & & C & $E$ & $E$ & $\begin{array}{l}\text { combustion products, like soot, can greatly } \\
\text { influence wear and friction; fuel combustion } \\
\text { products are a major contributor to engine } \\
\text { deposits, with lesser contribution from lubricant } \\
\text { (see also "deposits and soot") }\end{array}$ \\
\hline deposits / soot & $C$ & $C$ & C & $E$ & $E$ & $\begin{array}{l}\text { deposits forming on different parts of the piston } \\
\text { and liner have different compositions and } \\
\text { effects; carbon deposits in particular can affect } \\
\text { bore polishing, scuffing, and sticking; it has been } \\
\text { proposed that soot can remove anti-wear } \\
\text { lubricant additives, like ZDDP, and so increase } \\
\text { wear }\end{array}$ \\
\hline
\end{tabular}




\begin{tabular}{|c|c|c|c|c|c|c|}
\hline $\begin{array}{l}\text { lubricant - } \\
\text { composition }\end{array}$ & & & $\mathrm{C} / \mathrm{E}$ & $\mathrm{C} / \mathrm{E}$ & $E$ & $\begin{array}{l}\text { lubricant additives affect both friction and wear; } \\
\text { exposure to operating conditions can alter } \\
\text { composition which, in turn, changes the } \\
\text { operating conditions; studied showed potential } \\
\text { increases in frictional ring-pack loss of up to } 40 \% \\
\text { due to oil degradation; polymer additives can } \\
\text { benefit friction in certain lubrication regimes } \\
\text { (hydrodynamic), but not much in boundary } \\
\text { lubrication (see also "lubricant - regime") }\end{array}$ \\
\hline $\begin{array}{l}\text { lubricant - } \\
\text { cleanliness }\end{array}$ & & C & C & $\mathrm{E}$ & $\mathrm{E}$ & $\begin{array}{l}\text { presence of contaminants can cause abrasive } \\
\text { wear; contaminants include soot, machining } \\
\text { chips, sand from casting, road dust, wear } \\
\text { particles, additive precipitates, fuel combustion } \\
\text { products, ash (see also "filtration") }\end{array}$ \\
\hline lubricant - regime & C & C & C & $E$ & $\mathrm{E}$ & $\begin{array}{l}\text { boundary, mixed film, and hydrodynamic } \\
\text { lubrication can occur at different parts of the } \\
\text { piston stroke; surface separation, friction and } \\
\text { wear depend on the operating regime }\end{array}$ \\
\hline lubricant - viscosity & & & C & C/E & $\mathrm{E}$ & $\begin{array}{l}\text { lubricant viscosity affects the flow and film } \\
\text { formation of lubricants; too high and the lubricant } \\
\text { cannot flow where it is needed; too low and the } \\
\text { film will not support the bearing pressure causing } \\
\text { solid/solid contact; affected by temperature, } \\
\text { chemistry, and time of exposure to operating } \\
\text { conditions }\end{array}$ \\
\hline lubricant - windage & C & & $\mathrm{C} / \mathrm{E}$ & & & $\begin{array}{l}\text { drag of crankshaft can affect parasitic losses; oil } \\
\text { level in the crankcase has an effect on this }\end{array}$ \\
\hline filtration & C & & C & $\mathrm{E}$ & $\mathrm{E}$ & $\begin{array}{l}\text { affects the ability to remove contaminants from } \\
\text { lubricants and thus affects wear and viscosity }\end{array}$ \\
\hline liner bore materials & & & & $E$ & C/E & $\begin{array}{l}\text { affects the conformity of the components and the } \\
\text { changes in surface finish with time; run-in ability } \\
\text { affects longer term performance; wear particles } \\
\text { can enter the lubricant; wear resistance } \\
\text { increases engine life and durability }\end{array}$ \\
\hline
\end{tabular}



ORNL/TM-2001/184

\section{INTERNAL DISTRIBUTION}

1-20. Peter Blau, 4515, MS-6063

21-23. D. Ray Johnson, 4515, MS-6066

24. Ronald Ott, 4515, MS-6063

25. Arvid Pasto, 4515, MS-6062

26-28. Phil Sklad, 4515, MS-6065

29. Richard Ziegler, NTRC, MS-6472

30. Lab Records, $4500 \mathrm{~N}$, MS-625

31. Central Research Library, 4500N, MS-6191

\section{EXTERNAL DISTRIBUTION}

32. Gary C. Barber, Oakland University, Dept. of Mech. Engr., Rochester, MI 48309

33. Brad Beardsley, Caterpillar Inc., Tech. Center-E/854, P. O. Box 1875, Peoria, IL 61656-1875

34. Bruce Boardman, Deere and Company Tech. Center, 3300 River Drive, Moline, IL 61265-1792

35. David Cusac, Caterpillar Inc., Tech. Center-E/854, P. O. Box 1875, Peoria, IL 616561875

36. Amit Data, Advanced Components and Materials Inc., 1360 High Hawk Rd, East Greenwich, RI 02818

37. Sidney Diamond, U.S. Dept. of Energy (EE-33 FORS), 1000 Independence Ave. SW, Washington, DC 208-0121

38. Valery Dunaevsky, Bendix Commercial Vehicle Systems, 901 Cleveland St.Elyria, $\mathrm{OH} 44126$

39. James J. Eberhardt, U.S. Dept. of Energy (EE-33 FORS), 1000 Independence Ave. SW, Washington, DC 20585-0121

40. Ali Erdemir, Argonne National Laboratory, 9700 S. Cass Avenue (Bldg. 212), Argonne, IL 60439

41. George Fenske, Argonne National Laboratory, 9700 S. Cass Avenue (Bldg. 212), Argonne, IL 60439

42. Norm Gitis, President, CETR, 1711 Dell Avenue, Campbell, CA 95008

43. Brian Holtkamp, Falex Corporation, 1020 Airpark Drive, Sugar Grove, IL 605549585

44. Steven Hsu, National Institute of Standards and Technology, Bldg 223 Rm A-265, Gaithersburg, MD 20899

45. Lewis K. Ives, National Institute of Standards and Technology, Metallurgy Division, Bldg 223, Gaithersburg, MD 20899

46. Roy Kamos, Adiabatics, Inc., 3385 Commerce Drive, Columbus, IN 47201 
47. Frank Kelly, Manager, Caterpillar Inc., Tech. Center-E/854, P. O. Box 1875, Peoria, IL 61656-1875

48. Francis Lockwood, VP Techology, Valvoline, P.O. Box 14000, Lexington, KY 40512

49. Kenneth Ludema, Dept. of Mech. Engineering, University of Michigan, $2250 \mathrm{G}$. Brown Bldg., Ann Arbor, MI 48109-2125

50. Robert McCune, Ford Motor Company, P. O. Box 2053 (SRL-MD/2313), Dearborn, MI 48121-2053

51. Malcolm Naylor, Cummins Engine Company, Box 3005 (MC 50183), Columbus, IN 47202-3005

52. Joseph Perez, Dept. Chem. Engineering, Penn State University, 105 Fenske Lab, University Park, PA 16802-4400

53. Mark M. Shuster, Dana Corporation, Tech. Resource Park, 8000 Yankee Road, Ottawa Lake, MI 49267

54. Simon Tung, General Motors NAO R\&D Center - Fuels and Lubricants, 30500 Mound (MC480-106-160 CES Lab), Warren, MI 48090-9055

55. Yucong Wang, General Motors Powertrain, 77 West Center Street, Saginaw, MI 4860-5073

56. Pierre Willermet, Ford Motor Company, P. O. Box 2053 (SRL), Dearborn, MI 48121-2053

57. Ward O. Winer, Dept. Chairman, George W. Woodruff School of Mechanical Engineering, Georgia Institute of Technology, Atlanta, Georgia 30332-0405

58. Elaine Yamaguchi, Chevron Research and Tech Co., 100 Chevron Way, Richmond, CA 94802-0627

59. Thomas Yonushonis, Cummins Engine Company - Tech Ctr., Box 3005, Columbus, IN 47202-3005

60. Elmer Zanoria, Caterpillar Inc., Tech. Center, P. O. Box 1875, Peoria, IL 616561875 